\title{
SASKATCHEWAN FALCONRY ASSOCIATION RAPTOR BANDING - A SUMMATION
}

by Glen A. Fox, 65 Grange Street, Guelph, Ontario

The purpose of this report is to summarize the results to date of the Saskatchewan Falconry Association's banding program. The banding was carried out from 1960 through 1967 and was somewhat sporadic. The program has since been terminated and the efforts centralized under the supervision of Mr. Richard W. Fyfe, Canadian Wildlife Service, Edmonton. Some data previously published by Houston (1967, 1968) have been included for continuity. Detailed observations on nesting habits of some of the species banded have been published previously by Fox (1964) and
Sealy (1967), while others have been filed with the Prairie Nest Records Scheme. Our observations of food remains at the nest do not differ from those of other observers and will not be presented at this time.

In the period 1960 through 1967 the Association banded 267 raptorial birds of 14 species (see Tables 1 and 2). Ten of these banded birds have subsequently been recovered, all within a year of banding.

The owls appear to exhibit little movement from the nest site, and have a heavy mortality within their first six months of life. The Great

Table 1. Summary of S.F.A. Raptor Banding.

\begin{tabular}{|c|c|c|c|c|c|}
\hline Species & 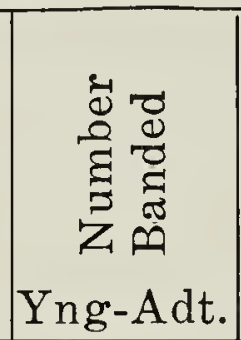 & 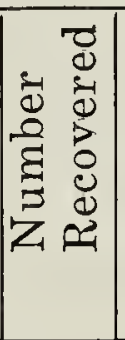 & 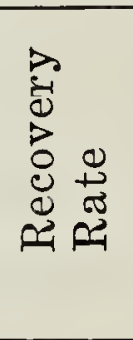 & $\begin{array}{l}\text { Brood Size } \\
\text { at Banding }\end{array}$ & Comments \\
\hline Turkey Vulture & $2-0$ & 0 & 0 & & courtesy of $\mathrm{A}$. Deutscher \\
\hline Red-tailed Hawk & $30-0$ & 1 & .03 & $1.5(1-2)$ & \\
\hline Swainson's Hawk & $7-1$ & 0 & 0 & $1.5(1-3)$ & $\begin{array}{l}\text { juvenile cannibalism in } \\
3 \text { of } 4 \text { nests }\end{array}$ \\
\hline Ferruginous Hawk & $17-0$ & 0 & 0 & $3.0(2-3)$ & \\
\hline Golden Eagle & $6-0$ & 1 & .16 & $1.5(1-2)$ & \\
\hline Bald Eagle & $2-0$ & 0 & 0 & & $\begin{array}{l}\text { courtesy of F. } \\
\text { Heidelbauer }\end{array}$ \\
\hline Marsh Hawk & $50-0$ & 2 & .04 & $4.0(1-5)$ & $\begin{array}{l}\text { juvenile cannibalism } \\
\text { noted twice }\end{array}$ \\
\hline Prairie Falcon & $45-1$ & 0 & 0 & & $\begin{array}{l}14 \text { courtesy of } \\
\text { J. Campbell }\end{array}$ \\
\hline Peregrine Falcon & $0-2$ & 0 & 0 & & $\begin{array}{l}\text { entangled in duck } \\
\text { bait-traps }\end{array}$ \\
\hline Pigeon Hawk & $10-1$ & 1 & .10 & & \\
\hline Sparrow Hawk & $31-0$ & 0 & 0 & & $\begin{array}{l}\text { of } 28 \text { spring migrants, } \\
64 \% \text { females }\end{array}$ \\
\hline Great Horned Owl & $42-1$ & 4 & .09 & $2.0(1-3)$ & \\
\hline Burrowing Owl & 9 & 0 & 0 & & \\
\hline Long-eared Owl & $10-1$ & 1 & .09 & $3.3(2-5)$ & \\
\hline 14 Species & $261-6$ & 10 & .37 & 2.4 & Totals and Means \\
\hline
\end{tabular}


Table 2. Summary of Recoveries to June 30, 1968.

\begin{tabular}{|c|c|c|c|}
\hline Species & Banded & Recovered & Status \\
\hline Red-tailed Hawk & $\begin{array}{l}11 \text { July ' } 60 \\
\text { Cando }\end{array}$ & $\begin{array}{l}17 \text { Jan. '61 } \\
\text { Alabama }\end{array}$ & -1 found dead \\
\hline Golden Eagle & $\begin{array}{l}3 \text { July '65 } \\
\text { Big Muddy }\end{array}$ & $\begin{array}{l}25 \text { Nov. '65 } \\
\text { Kansas }\end{array}$ & D found dead \\
\hline Marsh Hawk & $\begin{array}{ll}9 \text { July '60 } \\
\text { Battleford } \\
1 \text { July 'b1 } \\
\text { Battleford }\end{array}$ & $\begin{aligned} & 1 \text { Sept. '60 } \\
& \text { New Mexico } \\
& 22 \text { Jan. } 62 \\
& \text { Oklahoma }\end{aligned}$ & $\begin{array}{l}\text { D injured } \\
-1 \text { found dead }\end{array}$ \\
\hline Pigeon Hawk & $\begin{array}{l}5 \text { July '60 } \\
\text { Kindersley }\end{array}$ & $\begin{array}{ll}6 & \text { Feb. '61 } \\
& \text { Shaunavon }\end{array}$ & -1 found deac \\
\hline Great Horned Owl & $\begin{aligned} & 9 \text { June '60 } \\
& \text { Battleford } \\
& 6 \text { June '61 } \\
& \text { Battleford } \\
& 11 \text { June '61 } \\
& \text { Battleford } \\
& 13 \text { June '67 } \\
& \text { Dewar Lake }\end{aligned}$ & $\begin{array}{ll}14 \text { Aug. '60 } \\
\text { Battlefor'd } \\
28 \text { Dec. '61 } \\
\text { Battleford } \\
\text { Fall '62 } \\
\text { Battleford } \\
19 \text { Mar. '68 } \\
\text { Foremost, Alta. }\end{array}$ & $\begin{array}{l}\text { D found dead } \\
\text { D shot } \\
1 \text { shot } \\
-1 \text { found dead }\end{array}$ \\
\hline Long-eared Owl & $\begin{array}{l}30 \text { June '60 } \\
\text { Battleford }\end{array}$ & $\begin{array}{l}11 \text { July '60 } \\
\text { Battleford }\end{array}$ & D found dead \\
\hline
\end{tabular}

Key: $\quad-1=$ less than one year of age

$\mathrm{D}=$ recovered within same year as banded

Horned Owl banded at Dewar Lake and recovered near Foremost, Alberta, is an exception.

The Red-tailed Hawk, Golden Eagle, and Marsh Hawk all show a southerly migration and all were recovered in the southwestern United States.

The falcons appear to have a lower mortality rate than the other species banded, with only one recovery from the 89 individuals of four species banded.

The mean recovery rate, disregarding the owls, was approximately two per cent and represents recoveries from only four of 10 species banded. Only 20 per cent of the recovered birds were reported as "shot", the bulk being reported as "found dead". Brood size in our sample does not differ markedly from that in the literature, suggesting that our activities had little effect upon the nesting success of the birds involved.

\section{Acknowledgements}

I wish to thank Mr. B. Haysom and the other S.F.A. members who took part in the program. Mr. Richard Fyfe gave constant encouragement and Dr. Stuart Houston provided considerable assistance throughout much of the program. Mr. Spencer Sealy and Gary Anweiler, although not club members, were most cooperative and made major contributions. Mr. Harold Fisher assisted with much of the banding in the Battleford area. Mr. Frank Heidelbauer and Adam Deutscher both made valuable contributions. Mr. John Campbell banded Prairie Falcons on the Bow River system in 1966. Finally, I would like to thank the Canadian Wildlife Service and the Wildlife Branch, Department of Natural Resources for issuing the necessary permits and bands.

\section{LITERATURE CITED}

Fox, G. A. 1964. Notes on a western race of the Pigeon Hawk. Blue Jay, $22: 140-147$.

Houston, C. S. 1967. Recoveries of Red-tailed Hawks banded in Saskatchewan. Blue Jay, $25: 109-111$.

1968a. Recoveries of Marsh Hawks banded in Saskatchewan. Blue Jay, 26:12-13.

1968b. Recoveries of Swainson's Hawks banded in Saskatchewan. Blue Jay, 26:86-87.

Sealy, S. G. 1967. Notes on the breeding biology of the Marsh Hawk in Alberta and Saskatchewan. Blue Jay, $25: 63-69$. 